\title{
Dealing with Sexual Abuse in Adolescents
}

\section{Sexual abuse trauma in adolescents}

The human body is the receiver and keeper of the purest messages of love, longing and attraction, as well as the most burdensome information of violence, cruelty and malice, ${ }^{1}$ including all types of violence and abuse. Sexual abuse is a traumatic experience that affects the victim irrespective of age, gender and the frequency of events, even if the victim does not remember it. Sexual abuse includes a wide range of sexual behaviors, as it is not limited to forced sexual intercourse, i.e. rape. Any type of sexual abuse is violence against the body, even if there is no physical violence or penetration. ${ }^{2}$

There are different definitions of sexual abuse and sexual violence. Williams ${ }^{3}$ defined child sexual abuse as sexual contact that is against the

\footnotetext{
1 C. Gostečnik, Relacijska paradigma in travma [Relational paradigm and trauma], Ljubljana 2008, Brat Frančišek in Frančiškanski družinski inštitut.

2 T. Repič Slavič, Nemi kriki spolne zlorabe in novo upanje [Silent screams of sexual abuse and a new hope], Celje: Celjska Mohorjeva družba 2015, Društvo Mohorjeva družba.

3 L. M. Williams, Recall of Childhood Trauma: A Prospective Study of Women's Memories of Child Sexual Abuse, "Journal of Consulting and Clinical Psychology" 62 (1994) 6,
} 
will of the child, and involves force or coercion by the offender who is at least five years older than the victim. Sanderson ${ }^{4}$ defined child sexual abuse, somewhat more broadly, as the involvement of a subordinate child and minor in sexual activities with an adult or any bigger or older person where there is a difference in age, power or size, and in which the child is used as a sexual object to satisfy the perpetrator's needs or desires, whereby the child, due to the disproportion in power or physical and/or psychological incapacity, has no choice or will to consent to sexual activity.

In addition to these and other definitions of sexual abuse, the following criteria are used to determine sexual abuse: the intention or reaction of the offender, the reaction of the victim, the use of force, exploitation, a lack of consent and premature development maturity. ${ }^{5} \mathrm{~A}$ negative and endangering experience is "traumatic" if it overwhelms the individual's ability to cope psychologically and physically and adapt to the stressful event. ${ }^{6}$ Relational trauma during adolescence, especially the trauma of sexual abuse, thus deeply affects the individual and his organic memory. ${ }^{7}$

\subsection{The dimensions and consequences of sexual abuse}

The huge problem of violence in modern society is highlighted by a wide variety of statistics and normative social arrangements. The World Health Organization $^{8}$ estimates show that a quarter of adults were physically abused in childhood, and one woman out of five was sexually abused as a child.

pp. 1167-1176.

4 C. Sanderson, Counselling Adult Survivors of Child Sexual Abuse. London: Philadelphia 2006, Jessica Kingsley Publishers.

5 T. Repič Slavič, Nemi kriki spolne zlorabe in novo upanje [Silent screams of sexual abuse and a new hope], Celje: Celjska Mohorjeva družba 2015, Društvo Mohorjeva družba.

6 M. Rosenthal, Your Life After Trauma, Powerful Practices to Reclaim Your Identity, New York, London, 2015, W. W. Norton \& Company.

7 C. Gostečnik, Relacijska paradigma in travma [Relational paradigm and trauma], Ljubljana 2008, Brat Frančišek in Frančiškanski družinski inštitut. C. Gostečnik, T. Repič Slavič, T. Pate, R. Cvetek, Body Language in Relational Family Therapy, "Journal of Religion \& Health” 57 (2018) 4, pp. 1538-1553. T. Repič Slavič, Nemi kriki spolne zlorabe in novo upanje [Silent screams of sexual abuse and a new hope], Celje: Celjska Mohorjeva družba 2015, Društvo Mohorjeva družba. T. Repič Slavič, C. Gostečnik, Relational family therapy as an aid toward resolving the trauma of sexual abuse in childhood in the process of separation in the couple relationship, "Journal of marital and family therapy" 43 (2017) 3, pp. 422-434.

8 World Health Organization, Global status report on violence prevention 2014, http://www.who.int/violenceprevention/approach/definition/en/ (10.11.2018). 
According to some data from North America, even about a quarter of those who have committed a sexual assault were adolescents. ${ }^{9}$ Sexual abuse is exposed as the most likely - as well as the most stigmatizing - form of child maltreatment. There is a higher prevalence of childhood sexual abuse among girls than among boys, as every fourth girl and every sixth boy is assumed to be sexually abused. ${ }^{10}$ Although there are no uniform estimates of the prevalence of sexual abuse, there is a certain consensus on the basis of meta studies showing that up to $20 \%$ of girls and slightly less than $10 \%$ of boys were sexually abused in childhood. ${ }^{11}$ In late adolescence, between 15 and 17 years of age, the risk of sexual abuse, especially among girls, is greatly increased. ${ }^{12}$

A number of studies have shown that sexual abuse in childhood and adolescence is a major risk factor for various psychological and other problems. ${ }^{13}$ The experience of childhood sexual abuse is generally linked

$9 \quad$ M. K. Allen, T. Superle, Youth crime in Canada, 2014. Juristat: Canadian Centre for Justice Statistics, 2016, http://www.statcan.gc.ca/pub/85-002-x/2016001/article/14309-eng. htm (10.11.2018). D. Finkelhor, R. Ormrod, M. Chaffin, Juveniles who commit sex offenses against minors. Office of juvenile justice and delinquency prevention (NCJ publication no. 227763), 2009, https://www.ncjrs.gov/pdffiles1/ojjdp/227763.pdf (10.11.2018). J. A. Spearson Goulet, M. Tardif, Exploring sexuality profiles of adolescents who have engaged in sexual abuse and their link to delinquency and offense characteristics, "Child abuse \& Neglect" 82 (2018), pp. 112-123.

10 D. Finkelhor, A. Shattuck, H. A. Turner, S. L. Hamby, The lifetime prevalence of child sexual abuse and sexual assault assessed in late adolescence, "Journal of Adolescent Health" 55 (2014), pp. 329-333.

11 D. Finkelhor, A. Shattuck, H. A. Turner, S. L. Hamby, The lifetime prevalence of child sexual abuse and sexual assault assessed in late adolescence, "Journal of Adolescent Health" 55 (2014), pp. 329-333. N. Pereda, G. Guilera, M. Forns, J. Gomez-Benito, The international epidemiology of child sexual abuse: A continuation of Finkelhor (1994), "Child Abuse and Neglect” 33 (2009) 6, pp. 331-342. L. E. Prino, C. Longobardi, M. Settanni, Young Adult Retrospective Reports of Adverse Childhood Experiences: Prevalence of Physical, Emotional, and Sexual Abuse in Italy, "Archives of Sexual Behavior" 47 (2018) 6, pp. 1769-1778. T. Repič Slavič, Nemi kriki spolne zlorabe in novo upanje [Silent screams of sexual abuse and a new hope], Celje: Celjska Mohorjeva družba 2015, Društvo Mohorjeva družba.

12 D. Finkelhor, A. Shattuck, H. A. Turner, S. L. Hamby, The lifetime prevalence of child sexual abuse and sexual assault assessed in late adolescence, "Journal of Adolescent Health" 55 (2014), pp. 329-333.

13 A. Brown, D. Finkelhor, Impact of child sexual abuse: A review of the research, "Psychological Bulletin" 99 (1986) 1, pp. 66-77. D. Finkelhor, Early and long-term effects of child sexual abuse: An update, "Professional Psychology" 21 (1990) 5, pp. 325-330. F. W. Putnam, Ten-year research update review: Child sexual abuse, "Journal of the American Academy of Child and Adolescent Psychiatry” 42 (2003) 3, pp. 269-278. 
with various symptoms and disorders in adolescents, primarily depression, anxiety, substance abuse, self-injury, somatic disorders and poor self-esteem. ${ }^{14}$

Among the concrete short-term consequences of sexual abuse trauma, those mentioned most often are: unwanted pregnancy, the risk of abortion, the risk of sexually transmitted diseases, gynecological infections, urinary bladder infections, abrasions and tears on various parts of the body, blue and red marks on the skin, sleep disorders, chronic fatigue and exhaustion, self-injury, self-neglect, provocative clothing, eating disorders, very painful periods, fearfulness and apprehension, depression and withdrawal, problems with concentration, emotional irritability, aggression, promiscuous behavior, etc. Some short-term consequences can also be expressed as longterm ones and vice versa. Long-term consequences that more often occur after several years, include post-traumatic stress disorder, social phobias, fear and anxiety, guilt and shame, substance abuse and eating disorders, running away from home, depression and suicide, panic attacks, excessive lack of trust, sexual dysfunctions, personality disorders and dissociation, revictimization and low self-esteem. ${ }^{15}$

On the other hand, a study showed that depressive symptoms in adolescent girls with a history of sexual abuse did not differ significantly from those in adolescents without the experience of sexual abuse; however, there were more self-destructive behaviors and problems in relationships with parents and peers in adolescents with the experience of abuse. ${ }^{16}$ Research findings have led to the link between sexual abuse in childhood and maladapted or

14 A. Hudson., C. Wekerle, A. L. Goldstein, S. Ellenbogen, R. Waechter, K. Thompson, S. H. Stewart, Gender Differences in Emotion-Mediated Pathways from Childhood Sexual Abuse to Problem Drinking in Adolescents in the Child Welfare System, "Journ Child Adol Trauma" 10 (2017) 1, pp. 19-28; F. W. Putnam, Ten-year research update review: Child sexual abuse, "Journal of the American Academy of Child and Adolescent Psychiatry" 42 (2003) 3, pp. 269-278; A. Sawyerr, B. Christopher, Child Sexual Abuse and Adolescent and Adult Adjustment: A Review of British and World Evidence, with Implications for Social Work, and Mental Health and School Counselling, "Advances in Applied Sociology" 7 (2017), pp. 1-15. K. Tossone, M. Wheeler, F. Butcher, J. Kretschmar, The Role of Sexual Abuse in Trauma Symptoms, Delinquent and Suicidal Behaviors, and Criminal Justice Outcomes Among Females in a Juvenile Justice Diversion Program, "Violence Against Women" 24 (2018) 8, pp. 973-993.

15 T. Repič Slavič, Nemi kriki spolne zlorabe in novo upanje [Silent screams of sexual abuse and a new hope], Celje: Celjska Mohorjeva družba 2015, Društvo Mohorjeva družba.

16 A. Leboeuf, J. J. Breton, C. Berthiaume, B. Balan, C. Huynh, J.-M. Guile, R. Labelle, Exploratory Study of the Clinical Characteristics of Adolescent Girls with a History of Physical or Sexual Abuse Consulting in a Mood Disorder Clinic, "Journal of the Canadian Academy of Child and Adolescent Psychiatry" 26 (2017) 2, pp. 114-118. 
disturbed sexual behavior in adolescence, including sexual preoccupation. ${ }^{17}$ In individuals who have experienced childhood sexual abuse, there is a higher probability of repeated abuse in adolescence and / or post-traumatic stress disorder in adulthood. ${ }^{18}$

\subsection{The brain and the child's response to trauma}

Every traumatic event leaves the strongest traces in the very body of the traumatized person. ${ }^{19}$ Even if the traumatic event does not remain in explicit memory, it is always remembered by the body. A survey of women in the USA who had been sexually abused in childhood showed that as many as $38 \%$ did not remember the abuse, which was particularly influenced by their young age at the time of abuse and by the fact that they knew the perpetrator. ${ }^{20}$ The life of an individual after trauma can be described as the functioning of a victim whose thoughts are in the present and whose body is in the past, as their body is permeated with the same affects as during the traumatic period. ${ }^{21}$

The child brain, which is still developing, has a lot of potential and flexibility, but it is also very sensitive and vulnerable, especially in an unpredictable, neglecting and abusive environment. ${ }^{22}$ The brain structure in abused and neglected children and adolescents is reflected in hemispherical lateralization and reduces the integration between the left and right

17 J. G. Noll, P. K. Trickett, F. W. Putnam, A prospective investigation of the impact of child sexual abuse on the development of sexuality, "Journal of Counseling and Clinical Psychology" 71 (2003) 3, pp. 575-586.

18 S. M. Hannan, H. K. Orcutt, L. R. Miron, K. L. Thompson, Childhood Sexual Abuse and Later Alcohol-Related Problems: Investigating the Roles of Revictimization, PTSD, and Drinking Motivations Among College Women, "Journal of Interpersonal Violence" 32 (2017) 14, pp. 2118-2138.

19 C. Gostečnik, Relacijska paradigma in travma [Relational paradigm and trauma], Ljubljana 2008, Brat Frančišek in Frančiškanski družinski inštitut.

20 L. M. Williams, Recall of Childhood Trauma: A Prospective Study of Women's Memories of Child Sexual Abuse, "Journal of Consulting and Clinical Psychology" 62 (1994) 6, pp. 1167-1176.

21 C. Gostečnik, Relacijska paradigma in travma [Relational paradigm and trauma], Ljubljana 2008, Brat Frančišek in Frančiškanski družinski inštitut. M. Rosenthal, Your Life After Trauma, Powerful Practices to Reclaim Your Identity, New York, London, 2015, W. W. Norton \& Company.

22 J. A. Cohen, A. P. Mannarino, E. Deblinger, Treating trauma and traumatic grief in children and adolescents, New York, NY, 2006, Guilford Press. 
hemispheres. In abused and neglected children and adolescents, the latter is much more active, which is not in accordance with normal development. The development of the left hemisphere is thus slow, and children and adolescents therefore reflect and express stronger feelings which they are not able to regulate adequately. The perception and expression of emotions and affects, especially negative and unpleasant ones, is the domain of the right hemisphere, while the left hemisphere is focused on the perception and expression of language, and on logical and analytical thinking. The communication between the two hemispheres occurs through a thick bundle of fibers, the corpus callosum. Excessive release of stress hormone (cortisol) adversely affects the corpus callosum, reducing its volume, thus inhibiting the communication between the hemispheres, which can lead to emotional and behavioral problems and dissociations. ${ }^{23}$

Research in neuroscience has shown that the experience of sexual abuse in childhood is associated with irregularities in cortical and subcortical areas of the brain ${ }^{24}$ and the development of post-traumatic stress disorder associated with smaller gray matter volume in the anterior cingulata corte ${ }^{25}$ and the irregularities of the corpus callosum in adolescents. ${ }^{26}$

Stress is a normal biological process (both psychological and physical) that is triggered in life-threatening moments, such as death, injuries, violence and other psychological-physical challenges. Brain functions allow the human body to cope with various forms of stress. The most recognizable response to stress or a traumatic event is the activation of the autonomic nervous system; the sympathetic nervous system triggers the secretion of hormones that prepare an individual to face the danger, i.e. fight-orflight response. In the period of stress, emotional irritability, muscular

23 C. Gostečnik, Relacijska paradigma in travma [Relational paradigm and trauma], Ljubljana 2008, Brat Frančišek in Frančiškanski družinski inštitut.

24 L. Blanco, L. A. Nydeger, G. Camarillo, D. R. Trinidad, E. Schramm, S. L. Ames, Neurological changes in brain structure and functions among individuals with a history of childhood sexual abuse: A review, "Neuroscience and Biobehavioral Reviews" 57 (2015), pp. 63-69.

25 M. A. W. Rinne-Albers, S. J. A. van der Werff, M. J. van Hoof, N. D. van Lang, F. Lamers-Winkelman, S. A. Rombouts, R. R. J. M. Vermerien, N. J. A. van der Wee, Abnormalities of white matter integrity in the corpus callosum of adolescents with PTSD after childhood sexual abuse: a DTI study, »Eur Child Adolesc Psychiatry« 25 (2016), pp. 869-878.

26 M. A. W. Rinne-Albers, J. N. Pannekoek, M. J. van Hoof, N. D. van Lang, F. Lamers-Winkelman, S. A. Rombouts, N. J. A. van der Wee, R. R. J. M. Vermerien, Anterior cingulate cortex grey matter volume abnormalities in adolescents with PTSD after childhood sexual abuse, »European Neuropsychopharmacology« 27 (2017), pp. 1163-1171. 
and digestive problems, sleep disorders and mood disorders, and various physical responses (e.g. increased blood pressure, accelerated heartbeat, sweaty palms, palpitations and dizziness) are often present.

When the danger is over, parasympathetic nervous system is triggered, which alleviates stress responses. If the stress response persists or if the fightor-flight response is not possible, freezing may occur or stress is transformed into post-traumatic stress disorder. The child's response is equipped with two types of response to trauma. In the first phase of a threat, an alarm reaction or arousal is triggered. If the child does not get an appropriate response in this state, the second phase of freezing occurs, which is reflected in psychological dissociation and physical numbness. An abnormal response to stress or trauma can lead to post-traumatic stress disorder. This disorder is most commonly expressed in recurrent intrusive memories and thoughts, a tendency to avoidance, mood changes, and increased arousal. ${ }^{27}$

We can conclude that the trauma of sexual abuse is very intensely related to the functioning of the brain and the hormonal system, as it can cause serious brain damage and changes in individual brain structures. An additional element of sexual abuse trauma, especially if it occurred early in life, is that the victim is not aware of it and that it is engrained in implicit memory, which does not, however, prevent its effect on the victim's activity and behavior. Due to dissociation, it is difficult to detect, but even if it is detected, it is difficult to determine its significance and intensity in spite of clearly manifested symptoms. Symptoms are evident in behavioral, emotional, somatic and cognitive areas, as well as in sexuality, ${ }^{28}$ which we will discuss below.

27 C. Gostečnik, Relacijska paradigma in travma [Relational paradigm and trauma], Ljubljana 2008, Brat Frančišek in Frančiškanski družinski inštitut. M. Rosenthal, Your Life After Trauma, Powerful Practices to Reclaim Your Identity, New York, London, 2015, W. W. Norton \& Company.

28 T. Repič Slavič, Nemi kriki spolne zlorabe in novo upanje [Silent screams of sexual abuse and a new hope], Celje: Celjska Mohorjeva družba 2015, Društvo Mohorjeva družba. 


\section{Experiencing and acting out of sexual abuse in adolescence}

\subsection{Experiencing the effects of sexual abuse}

Data show that young people who have not experienced sexual abuse have significantly higher level of self-control, more positive relationships with others, clearer life goals and a higher level of self-acceptance than adolescents who have experienced sexual abuse. For the latter, it is very difficult to accept their qualities, and they show disappointment and frustration as a result of past experiences. ${ }^{29}$

In adolescents who remain in the aroused state for a long time, there is an increased probability of chronic stress, depression, outbursts of rage, memory loss, intrusive thoughts, nightmares, flashbacks, learning difficulties, excessive vigilance, arousal, lack of speech, attention problems, reduced responsiveness to stress, and malfunction of biological systems (e.g. digestive system, immune system, regulatory systems for controlling hunger, sex, etc.). ${ }^{30}$ Childhood sexual abuse generally means that the child has been seduced into an abusive relationship, and that because of his own powerlessness and dependence on the adult or an older person, he could not protect himself. In such a relationship, the older person is the perpetrator, and the child is the victim. ${ }^{31}$

Severe traumas in early childhood, and also later, are imprinted in the psycho-organic structure of the individual, and traumatic experiences are transmitted through the mechanism of projection-introjection identification and are repeated and expressed in different ways over and over again in later life. Thus, the victim of sexual abuse will repeat the role of the victim in various life situations and relationships, especially in sexuality. Painful experiences and affects which are stored in the individual as traumatic

29 N. Shree, M. Y. Manjula, Psychological well-being among the adolescents who have experienced and who have not experienced sexual abuse, "Indian Journal of Health and Wellbeing" 8 (2017) 4, pp. 294-296.

30 M. Rosenthal, Your Life After Trauma, Powerful Practices to Reclaim Your Identity, New York, London, 2015, W. W. Norton \& Company.

31 C. Gostečnik, Relacijska paradigma in travma [Relational paradigm and trauma], Ljubljana 2008, Brat Frančišek in Frančiškanski družinski inštitut. T. Repič Slavič, Nemi kriki spolne zlorabe in novo upanje [Silent screams of sexual abuse and a new hope], Celje: Celjska Mohorjeva družba 2015, Društvo Mohorjeva družba. 
experiences, are projected outwardly, therefore the victim is again playing certain roles and states: although they are painful, they are the reminders of unresolved trauma. For example, the victim continues to identify with the traumatic psycho-organic states and causes herself the pain that was previously caused by the perpetrator. Violence and the affects of abuse, which only recreate a similar abusive atmosphere and distress, awaken in the victim's body, so the victim finds herself in situations and relationships where she is wounded again, or this time she wounds others. ${ }^{32}$

The worst thing is that the child has no words for abuse, he feels guilty and responsible, especially if and when his body enjoyed abuse. If later in life this person talks about this, he also tells that he intuitively knew as a child that something was wrong, but simply lacked words for it. Shame, disgust and guilt are the feelings that primarily belong to the perpetrator, the so called executioner, but through the projection-introjection identification, they are transmitted into the child where they are internalized. ${ }^{33}$

\subsection{Behavioral patterns after sexual abuse}

Due to the cruelty of the abuse, the child most often freezes, becomes silent and dissociates, which depends in particular on the age at which abuse occurred. The child's brain is too fragile to be able to process abuse - if it did, the child could die because of the cruelty of the act. Therefore, the abused use different behaviors or defenses to survive, and these defenses can become established forms of functioning long into adolescence and adulthood:

Victims often belittle themselves, as if nothing extraordinary has happened, or diminish the significance of abusive acts or even generalize them in the sense that they also happen to others, etc.

Victims even deny abuse and. in this way. believe that it has not occurred at all. The opposite of denial is the forgetting, as the victim escapes the reality and suppresses her feelings so that she does not even remember them. A split (dissociation) can be so severe that it can cause dissociative disorders.

32 C. Gostečnik, T. Repič Slavič, T. Pate, R. Cvetek, Body Language in Relational Family Therapy, "Journal of Religion \& Health" 57 (2018) 4, pp. 1538-1553.

33 C. Gostečnik, Relational Family Therapy. The Systemic, Interpersonal, and Intrapsychic Experience, New York, 2017, Routledge. 
Rationalization is another defense where the victim rationalizes abuse and finds the reasons to justify the perpetrator's actions.

Constant alertness, control and perfectionism are related behaviors. Control gives the victim a sense of security that was lacking at the time of abuse, as well as constant caution and vigilance to changes in the environment that provide some predictability, but are very tiring; even so, the victim cannot relax, as this could mean danger and unpredictability, as used to be the case at the time of abuse.

When the victim finds herself in circumstances similar to those at the time of abuse, she freezes, and she can even become totally physically, emotionally or intellectually paralyzed.

By means of mental absence, being constantly busy (excessive workload) and unhealthy humor (black humor, cynicism), the victim can create a distance, i.e. escapes pain and pretends that nothing has happened.

Abuse can also lead to other extreme behaviors, such as theft, lying, and even religious fanaticism. The victim has repeatedly been told that abuse is a secret so she must not tell anyone about it, or she is simply terrified and ashamed that others might find out about it, so she can become skillful in hiding the truth and at evasion; however, these are only a cry for help pointing to her pain. Very strict religious rules can give the victim a sense of security or a comforting belief that this had to happen, that it was God's will, etc. ${ }^{34}$

In childhood, the victim acts out her distress in various ways. She often shows it through play with her peers so that they hint at sexual intercourse between adults. Interestingly, children who are victims of sexual abuse usually find peers with similar experiences. The child knows intuitively and also physically (through an extraordinary attraction), who can and who cannot get involved in this kind of play. Such peer simply "smells right". Children who have experienced sexual abuse often show their distress through excessive masturbation, thereby trying to calm the body and alleviate its distress. During such masturbation, children rub against various objects, toys and edges. However, this activity never has a calming effect, which children crave, nor do they orgasm, since their body is not yet ready for it. Over and over again, this results in even greater distress which they cannot resolve themselves, and at the same time they feel that something is wrong with them, they feel disgusting, and they are ashamed to talk about

34 Bass and Davis in T. Repič Slavič 2015 (see note 2). 
it. Because of this behavior, children are often shamed by others (peers, siblings, parents, care-givers, etc.) that cannot or do not want to recognize distress in a child who, through masturbation, acts out the cruel abuse that occurred in the past or is still going on. ${ }^{35}$

Early sexual abuse can lead to further sexual revictimization during adolescence, which can manifest in various ways, for example, through contacts with sexually abusive peers, exposure to hazardous situations, risky sexual behavior, and sexual survival strategies. ${ }^{36}$ In puberty, sexual abuse can be acted out in various ways, in particular by risky sexual behavior, such as an early onset of sexual intercourse, changing (sexual) partners, promiscuous behavior, exhibitionism, sexually transmitted diseases, HIV, sex-related work (prostitution), unprotected sex, the use of drugs and alcohol in combination with sex, etc. Such sexual behavior is often accompanied by other forms of violence and poor family circumstances. ${ }^{37}$

Individuals suffering from such trauma perceive their body as disgusting, they feel guilty, embarrassed, angry, sad, and frightened. Because they usually cannot verbally express all these feelings that have accumulated in them, they may cry for help through various forms of acting out. For example, they want to attract attention to their mood through their grades (both bad as well as excellent), indiscipline, behavior among peers and selfdestructive behavior, they often fall in love with different persons and feel guilty even towards their boy- or girlfriends if these fall in love with them, in the sense that they must return their love because of their incessant feelings

35 C. Gostečnik, Relacijska paradigma in travma [Relational paradigm and trauma], Ljubljana 2008, Brat Frančišek in Frančiškanski družinski inštitut. T. Repič Slavič, Nemi kriki spolne zlorabe in novo upanje [Silent screams of sexual abuse and a new hope], Celje: Celjska Mohorjeva družba 2015, Društvo Mohorjeva družba.

36 S. M. Hannan, H. K. Orcutt, L. R. Miron, K. L. Thompson, Childhood Sexual Abuse and Later Alcohol-Related Problems: Investigating the Roles of Revictimization, PTSD, and Drinking Motivations Among College Women, "Journal of Interpersonal Violence" 32 (2017) 14, pp. 2118-2138. R. Maniglio, Significance, Nature, and Direction of the Association Between Child Sexual Abuse and Conduct Disorder: A Systemic Review, "Trauma Violence \& Abuse" 16 (2015) 3, pp. 241-257.

37 A. A. Hughes, R. A. Bean, J. M. Harper, Sexual Abuse and Subsequent Risky Sexual Behaviors: A Competency Model for Treatment of Adolescent Females, "American Journal of Family Therapy" Vol. 43 (2015) 4, pp. 326-338. T. E. Senn, M. P. Carey, P. A. Vanable, Childhood and adolescent sexual abuse and subsequent sexual risk behavior: Evidence from controlled studies, methodological critique, and suggestions for research, "Clinical Psychology Review” 28 (2008), pp. 711-735. 
of guilt. They are often regarded as "easy", as everyone around them sees that they can fall in love with different peers more often and more quickly than others (mostly on the basis of the feelings of guilt).

It is also unfair that the very children who have been abused are more often abused by their peers (inappropriate touching at school, after school, at celebrations etc.). Since the affects of shame and disgust are too intense to be felt, these adolescents, through various defense mechanisms (denial, minimization, rationalization etc.) justify and explain the abusive behaviors of their perpetrators and live on, as long as their distress is too severe and they resort to new ways of escape, such as alcohol, drugs, pornography, promiscuous behavior, adrenaline activities, theft, doing things "in secret", etc., all in order to silence their distress and to re-live all those physical sensations that they experienced during abuse, in order for the situation to develop differently this time. ${ }^{38}$

\section{The processing of sexual violence in adolescence}

A prerequisite for adequate processing of sexual violence and abuse in adolescents is a safe environment where young people can talk about the cruel crime they were the victims of. To speak the truth that unconsciously or covertly screams is sometimes the most difficult, so an appropriate presence and sympathy of parents or caregivers and other adults is also necessary to feel and recognize the victim, especially when she is not able to do it herself.

\subsection{The disclosure of sexual abuse}

Studies have shown that only about a third of abused children and adolescents reveal abuse immediately or relatively soon after it has occurred (e.g. within one week or month). One third of the victims reveal abuse with a delay or later,

38 A. A. Hughes, R. A. Bean, J. M. Harper, Sexual Abuse and Subsequent Risky Sexual Behaviors: A Competency Model for Treatment of Adolescent Females, "American Journal of Family Therapy" Vol. 43 (2015) 4, pp. 326-338; T. Repič Slavič, Nemi kriki spolne zlorabe in novo upanje [Silent screams of sexual abuse and a new hope], Celje: Celjska Mohorjeva družba 2015, Društvo Mohorjeva družba. T. E. Senn, M. P. Carey, P. A. Vanable, Childhood and adolescent sexual abuse and subsequent sexual risk behavior: Evidence from controlled studies, methodological critique, and suggestions for research. "Clinical Psychology Review" 28 (2008), pp. 711-735. 
e.g. after one month or after a few years, while about a third only reveal abuse as an older child, adolescent, adult, or not at all. Victims who do not disclose abuse immediately are more susceptible to mood disorders and prone to delinquency. The consequences of prolonged silence about incestuous abuse within family are more serious, for example, the development of PTSD, selfaccusation etc. It is necessary to point out that, in many cases, victims do try to tell about abuse, but they are not heard and accepted, and even if they are, their disclosure is not followed by appropriate measures and help. In addition to the personality of the victim, relationships in the family play an essential role in such situations. Boys generally report abuse later than girls, fearing that they will be labeled homosexuals or victims. ${ }^{39}$

Furthermore, data shows that victims often reveal abuse to their peers, and more than a third never reveal it to their parents. If they do, they would sooner tell their mothers than fathers. The main reasons for this are the lack of trust in parents and the fear of worrying them. The victims will sooner disclose abuse if it was committed outside the family, if it was a one-time abuse, if their parents still live together and if the victim was older when the crime was committed. The disclosure of abuse is negatively linked to the feelings of guilt, fear, shame and the age of the perpetrator. Victims fear that they will not be believed, that they will be stigmatized and even punished (because they had sex etc., even though they were the victim of abuse). They are often afraid that disclosure will lead to conflict in the family or between the parents, if the perpetrator is one of the parents. The reasons for the non-disclosure of abuse are also the denial, or the deficient memory, or the misunderstanding of the abusive acts, in particular if they occurred prior to adolescence. The disclosure of abuse is, of course, a prerequisite for providing support, therapeutic intervention and concrete confrontation with the trauma. The sooner the abuse is revealed, and the sooner the processing of the abuse begins, the lesser the risk of short-term and long-term consequences for the victim; besides, the disclosure can also mean stopping the perpetrator in order to discontinue the abuse either of this victim or other victims. ${ }^{40}$

39 C. Townsend, Child sexual abuse disclosure: What practitioners need to know, Charleston, S.C., 2016, Darkness to Light. www.D2L.org (10.11.2018).

40 V. Scönbücher, T. Maier, M. Mohler-Kuo, U. Schnyder, M. A. Landolt, Disclosure of Child Sexual Abuse by Adolescents: A Qualitative In-Depth Study, "Journal of Interpersonal Violence" 27 (2012) 17, pp. 3486-3513. 


\subsection{The beginning of the healing process after sexual abuse}

Individuals who experienced sexual violence in their childhood can suffer from a broad range of negative effects in adulthood, as violence is engrained in their psycho-organic structure. Therefore, these individuals need professional help, in order to thoroughly transform their behavioral patterns, relationships and inner attitudes, so that they can break dysfunctional relationships, and above all, to escape the vicious circle of violence. This will also enable them to stop passing violence or its consequences on to the next generations. ${ }^{41}$

In the case of abuse, compassion on the part of adults, especially family and primary caregivers, is crucial, so that they hear and feel the child in his pain, providing support and safe shelter, which is essential for the child's continued and healthy psychological development. ${ }^{42}$ If sexual abuse occurs within the family, especially from parents, this is the cruelest and most unjustifiable experience. In case of incest, the child first experiences shock and utter confusion. This is followed by inappropriate feelings that he is dirty, abominable, embarrassed, humiliated, and even guilty of abuse, since he must have been the one who triggered and caused the abuse, who seduced his parent to commit this act. Since the child does not understand this violence and abuse, he remains alone in this trauma and without a way out. Emotionally, cognitively and physically the child is totally unprepared and not capable of responding to sexual arousal and, consequently, sexual intercourse by an adult. If a child does not succeed in this critical effort to get a positive response from others, his dissociation mechanism is activated and he turns inward. ${ }^{43}$

Silence or inadequate activity give rise to the development of various negative consequences, defenses and practices that regulate painful affects in the victim. Different symptoms, such as phobias, psychosomatic illnesses,

\footnotetext{
41 C. Gostečnik, Relacijska paradigma in travma [Relational paradigm and trauma], Ljubljana 2008, Brat Frančišek in Frančiškanski družinski inštitut. T. Repič Slavič, Nemi kriki spolne zlorabe in novo upanje [Silent screams of sexual abuse and a new hope], Celje: Celjska Mohorjeva družba 2015, Društvo Mohorjeva družba.

42 B. Simonič, Empatija: Moč sočutja v medosebnih odnosih [Empathy: The power of compassion in interpersonal relationships], Ljubljana, 2010, Brat Frančišek in Frančiškanski družinski inštitut.

43 C. Gostečnik, Relacijska paradigma in travma [Relational paradigm and trauma], Ljubljana 2008, Brat Frančišek in Frančiškanski družinski inštitut.
} 
drug and alcohol abuse, depression, eating disorders, self-injury and infidelity, can be understood as psychological constructs that cover deeper pain and deeper affects, in particular fear, shame and disgust. ${ }^{44}$ Sexual abuse can lead to the inability to regulate these affects, which remain deeply embedded in the child's psycho-organic structure, and can harm the victim later, in adolescence and adulthood, in particular in establishing intimate relationships. ${ }^{45}$ Clinical practice shows that adolescents and adults who were sexually abused as children, often sexualize their relationships and their manifestations of love. Since sexual abuse, especially by parents or care-givers, is so highly relational, it can be best understood and resolved within relational context. ${ }^{46}$ Victims thus begin to process sexual abuse at the cognitive level, first by admitting that abuse really happened, which is just the beginning of a difficult process bringing new hope. ${ }^{47}$

\section{Conclusion}

Sexual abuse is a traumatic experience that deeply affects the victim of abuse, especially early abuse, which the victim may not even remember. Any sexual abuse, which consists of a wide range of perverted sexual behaviors, is violence against the body. It is precisely because of the diversity of abusive sexual acts, especially those that are not known or "obvious" to the general population, that it often remains hidden or undisclosed for far too long. In any case, sexual abuse does not only mean a forced sexual intercourse

44 C. Gostečnik, Relational Family Therapy. The Systemic, Interpersonal, and Intrapsychic Experience, New York, 2017, Routledge. T. Repič Slavič, Nemi kriki spolne zlorabe in novo upanje [Silent screams of sexual abuse and a new hope], Celje: Celjska Mohorjeva družba 2015, Društvo Mohorjeva družba.

45 C. Gostečnik, Relational Family Therapy. The Systemic, Interpersonal, and Intrapsychic Experience, New York, 2017, Routledge.

46 T. Repič Slavič, C. Gostečnik, Relational family therapy as an aid toward resolving the trauma of sexual abuse in childhood in the process of separation in the couple relationship, "Journal of marital and family therapy" 43 (2017) 3, pp. 422-434.

47 T. Repič Slavič, Kognitivna raven kot del relacijske družinske terapije pri predelovanju spolnega nasilja [Cognition level as a part of a Relational Family Therapy and regulation of sexual abuse], in: Zbornik 21. mednarodne multikonference Informacijska družba - IS 2018, Zvezek B [Proceedings of the 21st International Multiconference Information Society], 8.12. oktober 2018 / 8-12 October 2018, Ljubljana, Slovenia. 
or rape. Sexual abuse that occurs in childhood or adolescence is not a rare phenomenon; according to some estimates, every fourth girl and every sixth boy is a victim of sexual abuse. Even if sexual abuse occurred prior to adolescence, it may be reflected in adolescence and later in adulthood through various dysfunctional behaviors or psychological and physical problems. The experience of sexual abuse is a major risk factor for the development of psychopathology and various negative short-term and long-term consequences in victims. Sexual abuse in adolescents is often associated with depression, substance abuse, self-injury, somatic disorders and poor self-esteem. There is an increasing number of neuroscientific findings showing that the trauma of sexual abuse is very closely related to the functioning of the brain and the hormone system, as it can cause serious brain damage. Such trauma is ingrained in the individual's psycho-organic structure and is transmitted through various non-functional patterns and defenses (e.g. denial, minimization, rationalization, dissociation, etc.). A characteristic of early sexual abuse is its repetition during adolescence, which often leads to revictimization. Sexual abuse is also reflected in various dysfunctional sexual behaviors, primarily in an early onset of sexual intercourse, changing sexual partners, sexual violence, sexual diseases, promiscuity, etc. Despite the fact that sexual abuse is a distressing phenomenon, its detection and disclosure are still unsatisfactory, as only about one third of the victims reveal abuse immediately, or soon after it happened. This can be also attributed to the fact that the majority of abuses occur within the family, which makes it difficult to disclose it. The disclosure of abuse and the perpetrator is, however, an indispensable prerequisite for the onset of the painful recovery process.

\section{Bibliography}

Allen M. K., Superle, T., Youth crime in Canada, 2014. Juristat: Canadian Centre for Justice Statistics, 2016, http://www.statcan.gc.ca/pub/85002-x/2016001/article/14309-eng.htm (10.11.2018).

Blanco L., Nydeger L. A., Camarillo G., Trinidad D. R., Schramm E., Ames S. L., Neurological changes in brain structure and functions among individuals 
with a history of childhood sexual abuse: A review, "Neuroscience and Biobehavioral Reviews" 57 (2015), pp. 63-69.

Briere J. N., Elliott D. M., Immediate and Long-Term Impacts of Child Sexual Abuse, "Sexual Abuse of Children" 4 (1994) 2, pp. 54-69.

Browne A., Finkelhor D., Impact of child sexual abuse: A review of the research, "Psychological Bulletin" 99 (1986) 1, pp. 66-77.

Cohen J. A., Mannarino A. P., Deblinger E., Treating trauma and traumatic grief in children and adolescents, New York, NY, 2006, Guilford Press.

Erickson M. F., Egeland B., Pianta R., The effects of maltreatment on the development of young children. V: Research and theory: Child maltreatment. Dante Cicchetti and Vicki Carlson, eds., London: Cambridge, 1989.

Finkelhor D., Early and long-term effects of child sexual abuse: An update, "Professional Psychology" 21 (1990) 5, pp. 325-330.

Finkelhor D., Ormrod R., Chaffin M., Juveniles who commit sex offenses against minors. Office of juvenile justice and delinquency prevention (NCJ publication no. 227763), 2009, https://www.ncjrs.gov/pdffiles1/ ojjdp/227763.pdf (10.11.2018).

Finkelhor D., Shattuck A., Turner H. A., Hamby S. L., The lifetime prevalence of child sexual abuse and sexual assault assessed in late adolescence, "Journal of Adolescent Health" 55 (2014), pp. 329-333.

Gostečnik C., Relacijska paradigma in travma [Relational paradigm and trauma], Ljubljana 2008, Brat Frančišek in Frančiškanski družinski inštitut.

Gostečnik C., Relational Family Therapy. The Systemic, Interpersonal, and Intrapsychic Experience, New York, 2017, Routledge.

Gostečnik C., Repič Slavič T., Pate T., Cvetek R., Body Language in Relational Family Therapy, "Journal of Religion \& Health" 57 (2018) 4, pp. 15381553.

Hannan S. M., MA, Orcutt H. K., Miron L. R., Thompson K. L., Childhood Sexual Abuse and Later Alcohol-Related Problems: Investigating the Roles of Revictimization, PTSD, and Drinking Motivations Among College Women, "Journal of Interpersonal Violence" 32 (2017) 14, pp. 2118-2138.

Hughes A. A., Bean R. A., Harper J. M., Sexual Abuse and Subsequent Risky Sexual Behaviors: A Competency Model for Treatment of Adolescent Females, "American Journal of Family Therapy", Vol. 43 (2015) 4, pp. 326-338. 
Hudson A., Wekerle C., Goldstein A. L., Ellenbogen S., Waechter R., Thompson K., Stewart S. H., Gender Differences in Emotion-Mediated Pathways from Childhood Sexual Abuse to Problem Drinking in Adolescents in the Child Welfare System, "Journ Child Adol Trauma” 10 (2017) 1, pp. 1928.

Leboeuf A., Breton J. J., Berthiaume C., Balan B., Huynh C., Guile J.-M., Labelle R., Exploratory Study of the Clinical Characteristics of Adolescent Girls with a History of Physical or Sexual Abuse Consulting in a Mood Disorder Clinic, "Journal of the Canadian Academy of Child and Adolescent Psychiatry” 26 (2017) 2, pp. 114-118.

Maniglio R., Significance, Nature, and Direction of the Association Between Child Sexual Abuse and Conduct Disorder: A Systemic Review, "Trauma Violence \& Abuse" 16 (2015) 3, pp. 241-257.

Noll, J. G., Trickett, P. K., Putnam, F. W., A prospective investigation of the impact of child sexual abuse on the development of sexuality, "Journal of Counseling and Clinical Psychology 71 (2003) 3, pp. 575-586.

Pereda N., Guilera G., Forns M., Gomez-Benito J., The international epidemiology of child sexual abuse: A continuation of Finkelhor (1994), "Child Abuse and Neglect" 33 (2009) 6, pp. 331-342.

Prino L. E., Langobardi C., Settanni M., Young Adult Retrospective Reports of Adverse Childhood Experiences: Prevalence of Physical, Emotional, and Sexual Abuse in Italy, "Archives of Sexual Behavior" 47 (2018) 6, pp. 1769-1778.

Putnam, F. W., Ten-year research update review: Child sexual abuse, "Journal of the American Academy of Child and Adolescent Psychiatry" 42 (2003) 3, pp. 269-278.

Repič Slavič T., Nemi kriki spolne zlorabe in novo upanje [Silent screams of sexual abuse and a new hope], Celje: Celjska Mohorjeva družba 2015, Društvo Mohorjeva družba.

Repič Slavič T., Kognitivna raven kot del relacijske družinske terapije pri predelovanju spolnega nasilja [Cognition level as a part of a Relational Family Therapy and regulation of sexual abuse], v: Zbornik 21. mednarodne multikonference Informacijska družba - IS 2018, Zvezek B [Proceedings of the 21st International Multiconference Information Society], 8.-12. oktober 2018 / 8-12 October 2018, Ljubljana, Slovenia. 
Repič Slavič T., Gostečnik C., Relational family therapy as an aid toward resolving the trauma of sexual abuse in childhood in the process of separation in the couple relationship, "Journal of marital and family therapy" 43 (2017) 3, pp. 422-434.

Rinne-Albers M. A. W., van der Werff S. J. A., van Hoof M. J., van Lang N. D., Lamers-Winkelman F., Rombouts S. A., Vermerien R. R. J. M., van der Wee N. J. A., Abnormalities of white matter integrity in the corpus callosum of adolescents with PTSD after childhood sexual abuse: a DTI study, "Eur Child Adolesc Psychiatry" 25 (2016), pp. 869-878.

Rinne-Albers M. A. W., Pannekoek J. N., van Hoof M. J., van Lang N. D., Lamers-Winkelman F., Rombouts S. A., van der Wee N. J. A., Vermerien R. R. J. M., Anterior cingulate cortex grey matter volume abnormalities in adolescents with PTSD after childhood sexual abuse, "European Neuropsychopharmacology" 27 (2017), pp. 1163-1171.

Rosenthal M., Your Life After Trauma, Powerful Practices to Reclaim Your Identity, New York, London, 2015, W. W. Norton \& Company.

Sanderson C., Counselling Adult Survivors of Child Sexual Abuse. London: Philadelphia 2006, Jessica Kingsley Publishers.

Sawyerr A., Christopher B., Child Sexual Abuse and Adolescent and Adult Adjustment: A Review of British and World Evidence, with Implications for Social Work, and Mental Health and School Counselling, "Advances in Applied Sociology" 7 (2017), pp. 1-15.

Scönbücher V., Maier T., Mohler-Kuo M., Schnyder U., Landolt M. A., Disclosure of Child Sexual Abuse by Adolescents: A Qualitative In-Depth Study, "Journal of Interpersonal Violence" 27 (2012) 17, pp. 3486-3513.

Senn, T. E., Carey, M. P., Vanable, P. A., Childhood and adolescent sexual abuse and subsequent sexual risk behavior: Evidence from controlled studies, methodological critique, and suggestions for research, "Clinical Psychology Review” 28 (2008), pp. 711-735.

Shree N., Manjula M. Y., Psychological well-being among the adolescents who have experienced and who have not experienced sexual abuse, "Indian Journal of Health and Wellbeing" 8 (2017) 4, pp. 294-296.

Simonič B., Empatija: Moč sočutja $v$ medosebnih odnosih [Empathy: The power of compassion in interpersonal relationships], Ljubljana, 2010, Brat Frančišek in Frančiškanski družinski inštitut. 
Spearson Goulet J. A., Tardif M., Exploring sexuality profiles of adolescents who have engaged in sexual abuse and their link to delinquency and offense characteristics, "Child abuse \& Neglect" 82 (2018), pp. 112-123.

World Health Organization, Global status report on violence prevention 2014, http://www.who.int/violenceprevention/approach/definition/en/ (10.11.2018).

Tossone K., Wheeler M., Butcher F., Kretschmar J., The Role of Sexual Abuse in Trauma Symptoms, Delinquent and Suicidal Behaviors, and Criminal Justice Outcomes Among Females in a Juvenile Justice Diversion Program, "Violence Against Women" 24 (2018) 8, pp. 973-993.

Townsend, C., Child sexual abuse disclosure: What practitioners need to know. Charleston, S.C., 2016, Darkness to Light. www.D2L.org (10.11.2018).

Verena S., Maier T., Mohler-Kuo M., Schnyder U., Landolt M. A., Disclosure of Child Sexual Abuse by Adolescents: A Qualitative In-Depth Study, "Journal of Interpersonal Violence" 27 (2012) 17, pp. 3486-3513.

Williams, L. M., Recall of Childhood Trauma: A Prospective Study of Women's Memories of Child Sexual Abuse, "Journal of Consulting and Clinical Psychology” 62 (1994) 6, pp. 1167-1176. 